\title{
Films as an Educational Resource in the Teaching of Humanistic Attitudes to Medicine Students
}

\author{
O Cinema como Recurso Educacional \\ no Ensino de Atitudes Humanísticas a \\ Estudantes de Medicina
}

\author{
Thaíla Soares da Costa Picanço ${ }^{\circledR}$ \\ Maira Tiyomi Sacata Tongu Nazima \\ Braulio Erison França dos Santos ${ }^{I}$ \\ Olavo Magalhães Picanço Júnior \\ Maria Izabel de Albuquerque Cambraia ${ }^{I}$ \\ Leila do Socorro da Silva Morais ${ }^{1}$ \\ Luis Felipe da Silva Pena \\ Karina Suzany Nery Costa
}

\section{PALAVRAS-CHAVE}

- Educação Médica.

- Cinema como Assunto.

- Humanização da Assistência.
Introdução: A educação médica contemporânea prioriza o desenvolvimento de conhecimento científico e habilidades técnicas, associados a atitudes profissionais. Atitudes são componentes da habilidade afetiva e influenciam a prática médica, por isso devem ser ensinadas sistematicamente durante a graduação. A utilização de filmes como recurso pedagógico na graduação médica possibilita uma reflexão no contexto biopsicossocial em que o paciente está inserido, contribuindo para desenvolver atitudes humanísticas entre estudantes de Medicina e futuros médicos. Objetivo: Avaliar a eficácia do cinema como recurso educacional no ensino de atitudes humanísticas aos discentes do curso de Medicina. Material e Métodos: Foi realizado um estudo transversal, exploratório, quantitativo, com 107 estudantes do primeiro ao sexto ano do curso de Medicina da Universidade Federal do Amapá. Foi utilizada a Escala de Atitude de Estudantes de Medicina (validada por Colares et al..$^{1}$ ) antes e depois da exibição de filmes relacionados a temáticas relevantes na área médica. Esta escala psicométrica é composta de respostas de múltipla escolha do tipo Likert e visa aferir atitudes de estudantes de Medicina em relação aos seguintes fatores: assistência primária à saúde; aspectos psicológicos e emocionais envolvidos nas doenças; aspectos éticos no exercício profissional; doença mental, situações relacionadas à morte; pesquisa científica. Foi empregado o Teste de Wilcoxon (Wilcoxon Rank Test) para comparar dados de amostras pareadas. Resultados: Todos os fatores avaliados pela escala de atitudes dos estudantes de Medicina frente a aspectos relevantes da prática médica apresentaram aumento significativo na frequência de atitudes positivas $(p<0,05)$ após as sessões de cinema entre os alunos do primeiro ao quarto ano da graduação. Os alunos do quinto e sexto ano não apresentaram mudança significativa de atitudes nos fatores relacionados à morte, à doença mental e à contribuição com o avanço científico da medicina. Conclusão: O cinema é uma ferramenta pedagógica eficaz no ensino de atitudes humanísticas a estudantes do curso médico. 


\section{KEY-WORDS}

- Medical Education.

- Films as Topic.

- Humanization of Assistance.

Recebido em 4/4/19

Aceito em 3/6/19
ABSTRACT

Introduction: Contemporary medical education prioritizes the development of scientific knowledge and technical skills, associated with professional attitudes. Attitudes are components of affective ability and influence medical practice, so they should be taught systematically during undergraduate training. The use of films as a pedagogical resource in medical training allows reflection on the biopsychosocial context in which the patient is inserted, contributing to the development of humanistic attitudes among students and future physicians. Objective: To evaluate the effectiveness of cinema as an educational resource in teaching humanistic attitudes to medical students. Material and Methods: A cross-sectional, quasi-experimental, qualitative and quantitative study was carried out with 107 students from the first to sixth year of the medical course of the Federal University of Amapá. The Medical Students Attitude Scale (validated by the author Maria de Fátima Colares, 2002) was used before and after the exhibition of films related to relevant themes in the medical area. This psychometric scale is composed of multiple-choice Likert-type responses and aims to assess the attitudes of medical students regarding the following factors: primary health care; psychological and emotional aspects involved in diseases; ethical aspects in professional practice; mental illness, death-related situations; scientific research. The Wilcoxon Rank Test was used to compare data from paired samples. Results: All the factors evaluated by the medical students attitudes scale related to relevant aspects of medical practice showed a significant increase in the frequency of positive attitudes $(p<0.05)$ among the first- to fourth-year students following the cinema sessions. The fifth-and sixth-year students did not present significant changes in attitudes related to death, mental illness and contribution to the scientific advancement of medicine. Conclusion: Cinema is an effective pedagogical tool in teaching humanistic attitudes in the preclinical series of the medical course.

\section{INTRODUCTION}

The context of medical education has undergone several changes in recent decades, based on findings that there was a lack of traditional medical courses training students with the characteristics expected of a future professional, such as communication skills, competence in performing practical tasks, aptitude for personal development and professionalism $^{2}$. Consequently, medicine schools have developed curricular reforms with the intention of implementing active teaching methodologies and providing students with the learning of these skills. Among the skills required for the training of future physicians, affective skills represent a challenge in the educational process, since there is no consensus about a training model for students regarding attitudes and behaviours related to medical practice ${ }^{3}$. Attitudes are components of affective skills and indicate an individual's willingness to act in favour of or against a stimulus, one can assess feelings and behaviours by virtue of such attitudes ${ }^{4}$.

The teaching of humanistic attitudes is considered essential in medical training, as an underlying competence required among health professionals ${ }^{5}$. Several strategies have been proposed to promote the teaching of humanistic attitudes during undergraduate medical training, including the incentive toward knowledge in the area of human sciences, so that students can recognise the sociocultural aspects of each individual and, thus, practice patient-centred medicine, as well as the development of evaluative methods with effective instruments capable of measuring the actual learning of the interpersonal skills foreseen in curricular grids ${ }^{6,7}$.

One way of approaching humanism in medicine during undergraduate training can be achieved by the adaptation of cinematographic films to the educational context ${ }^{8}$. The use of film as a pedagogical resource in medical teaching has proven to be an efficient tool, since, through the dramatization of situations related to the disease process, students can learn to understand and reflect on the biopsychosocial context in which the patient finds himself. Therefore, the experience with film for a medical student would represent an emotional memory that would heavily influence the development of attitudes related to the theme addressed through this teaching method ${ }^{9}$.

The assessment processes of Medicine courses are still very much geared toward cognitive evaluation, and, although 
several models for assessing technical skills have been developed recently, the assessment process of affective skills remains deficient. Therefore, the evaluation of medical students' attitudes takes on academic relevance, since any proof of the efficiency of the pedagogical tools adopted would enable the proposal of a program of interventions required to promote the systematic development of affective skills throughout the whole course.

\section{MATERIALS AND METHODS}

\section{Type of study}

An exploratory, cross-sectional, quantitative study was conducted.

\section{Study population}

The participants of the study were first- to sixth-year students from the Medicine course of the Federal University of Amapá in 2016, who were willing to participate in the proposed intervention and answer the questionnaires. The study sample consisted of a total of 107 students; 27 from the first year, 23 from the third, 17 from the fourth, 21 from the fifth and 19 from the sixth year of the course.

\section{Inclusion and exclusion criteria}

The survey included students who were duly enrolled on the course and who accepted to take part in the study.

Students who had only watched one of the films or who did not partake in the discussions were excluded from the research.

\section{Research stages and methods}

On the first day of the study, two instruments were administered for data collection: a sociodemographic questionnaire, developed by the author, and the "Instrument for Assessing Medicine Students' Attitudes in view of Relevant Aspects of Medical Practice" (IAA), validated by Maria de Fátima Colares based on a 2002 study $^{1}$. Subsequently, the students watched the entire movie The Doctor, which tells the story of a successful doctor, whose behaviour changes after he is diagnosed with cancer. The protagonist finds himself interacting with medicine, the hospitals and other doctors from a new point of view, that of the patient.

Straight after the film session, there was a brief discussion that used some scenes from the film as examples to contextualize the student in the following aspects: the difference between the biomedical model and the biopsychosocial model of medical work; perception and management of the emotional dimensions involved in the doctor-patient relationship; sen- sitizing students to the recognition of the patient's emotional manifestations when faced with his or her loss of health; characterization of the phases of bereavement: denial, anger, negotiation, depression, acceptance ${ }^{10}$; recognition of humanized medical attitudes.

One week after the first cinema session, the second film, Still Alice was screened. This movie tells the story of a university professor with early-onset Alzheimer's Disease, portraying the changes in her professional and personal life with the progressive restrictions imposed on her by the neurological degenerative disease. The discussion that followed the presentation of this film broached the correlation of the clinical reasoning between the physical disease and the development of psychological reactions; the transformations of the family arrangements of mental health patients and the loss of autonomy suffered by those patients. After this discussion, the IAA was readministered with the aim of assessing whether there had been any significant change in the attitudes of the students who participated in the study after the intervention.

The films were screened at cinema theatres in the city of Macapá.

\section{Ethical procedures}

The project abides by the ethical principles for research involving humans, as exposed in CONEP Resolution 466/2012, and was submitted to the UNIFAP Research Ethics Committee, and approved under report number 1.693.248.

\section{Research instruments}

Two instruments were used for data collection. The first was a sociodemographic questionnaire, developed to build the profile of the UNIFAP Medicine student.

The second instrument used was the IAA, the scale intended to measure the medical students' attitudes in relation to the following factors:

- Factor 1: psychological and emotional aspects in organic and mental diseases. Composed of 11 questions, the objective is to verify the importance given by students to the patient's emotional state over the course of the disease;

- Factor 2: coping with situations related to death. Consisting of eight questions, the objective is to assess the difficulty encountered by students in situations related to death or dying;

- Factor 3: primary health care. Encompasses 11 statements about the importance of the general practitioner and the practice of preventive measures; 
- Factor 4: aspects related to mental health. Proposes eight statements to evaluate the students' feelings in relation to mental health;

- Factor 5: contribution with the scientific advance of medicine. Corresponds to six statements and aims to understand what the student thinks about the importance of research in the medical career;

- Factor 6: other aspects of the physician's role. Eight questions to analyse the students' attitudes in view of various aspects relative to the physician's role in primary and tertiary health care services.

For each item, there are five possible responses: 1 - entirely agree; 2 - partly agree; 3 - I'm in doubt; 4 - partly disagree; 5 - entirely disagree.

\section{Data analysis}

The students' sociodemographic data were analysed descriptively.

The data obtained through the Instrument for Assessing Medicine Students' Attitudes in view of Relevant Aspects of Medical Practice (IAA) were gathered into three groups of answers: one group containing the answer options 1 and 2, which indicate positive attitudes according to the behaviour adopted in relation to the question about a given factor; another representing options 4 and 5, indicating negative attitudes, and a final category for option 3, which signals the student's indecision regardless of the question.

On this scale, the scores of the factors are not negatively scaled, so the higher the score the worse the attitude. Therefore, to analyse the data in such a way as to obtain an average score for each factor, the statements were reversed in negative phrases. Consequently, all the questions stated in the negative (questions 2, 5, 9, 10, 14, 15, 16, 18, 20, 21, 22, 23, 28, 29, 31, 35, $38,40,41,43,47,49,50,51$ and 52) were inversely recalculated: $(1=5) ;(2=4) ;(4=2) ;(5=1)$.

A nonparametric hypothesis test was applied to analyse the difference between the students' positive answers before and after the film screenings. The Wilcoxon Rank Test was therefore employed to compare paired sample data. The following was considered: H0: median $=0$ (no difference in medians between the moments with and without intervention); $\mathrm{H} 1$ : median $\neq 0$ (difference in medians between moments with and without intervention). The level of significance used in the whole analysis was $\alpha=0.05$.

The study data were analysed with the aid of the program Statistical Package for Social Science, version 22.0 (SPSS).

\section{Assessment of the internal reliability of the scale}

Analysis of the internal consistency of the IAA was performed using Cronbach's Alpha, which gave a result of 0.94 prior to the intervention and 0.80 after the intervention, which were considered excellent and acceptable values, respectively.

\section{RESULTS AND DISCUSSION}

\section{Sociodemographic data}

One hundred and seven students participated in the study, 52 (48.6\%) of whom were male, and 55 (51.4\%) female. Age varied from 18 to 38 years, with a mean of 23.35 years.

The survey had a participation rate of $39.64 \%$ of the firstto fourth-year Medicine students in 2016. It is highlighted that the second year was excluded, as the participation rate of these students was below $10 \%$. It is likely that there was little interest on the part of these students in participating in an activity relative to the theme of Humanization. Among the medical intern students, in the fifth and sixth years of the course, $76.92 \%$ participated in the study.

In relation to the profile of the study sample, it was found that most the students were born in the state of Amapá (54.2\%), have a household income of more than eight minimum wages $(38.3 \%)$ and live with their families (62.6\%). Catholicism was indicated as the most prevalent religion (55.1\%). When questioned about which specialization they intended to follow once they had completed the medical course, $43.9 \%$ chose specialties related to medical practice.

\section{Students' attitudes after the intervention}

When the students' attitudes after the intervention were examined, the effectiveness of this method of teaching was evident, since all the factors assessed by the IAA scale presented significant increase in the frequency of positive attitudes $(\mathrm{p}<$ 0.05) (Graph 1).

These data corroborate the study conducted by McNeilly and Wengel ${ }^{11}$, who also demonstrated a significant increase in theoretical knowledge and positive attitudes in relation to the learning of psychotherapeutic methods among third-year medical students, using video clips from a television series that portrays the care routine in an accident and emergency unit as a pedagogical tool. The effectiveness of cinema in contributing to the teaching of humanistic attitudes in medical training can be explained by a conceptual model described in the literature by Shapiro and Rucker ${ }^{12}$, named the "Dom Quixote Effect". According to the authors, the effect provoked in the students by the films can be compared to the influence that the main character from the classic novel Dom Quixote exerts on the behaviour of his companion Sancho Panza. Being in the 
GRAPH 1

Graphic representation of the frequencies of positive and negative attitudes among UNIFAP Medicine students before and after the cinema sessions in research conducted in the city of Macapá in 2016.

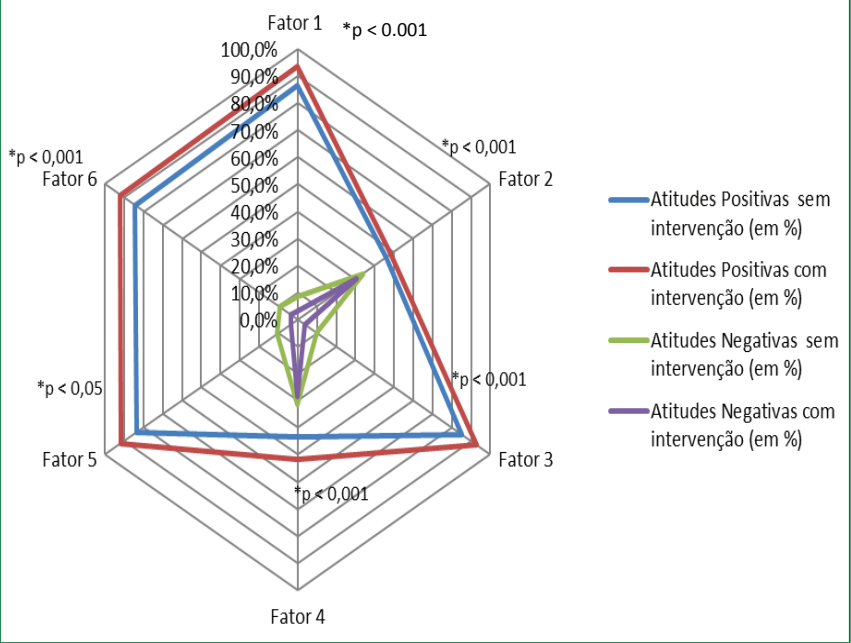

Source: Research record sheets.

Notes: Factor 1: psychological and emotional aspects in organic and mental diseases;

Factor 2: aspects related to death; Factor 3: primary health care; Factor 4: aspects related to mental health; Factor 5: contribution with the scientific advance of medicine; Factor 6: other aspects of the phsyician's role.

company of the idealist Dom Quixote acted as a trigger for a change in the values and attitudes of the pragmatic Sancho Panza. Likewise, when watching the film screenings, the students would be induced toward a temporary idealism.

Watching films that portray nuances of medical practice can contribute more to medical students and residents developing empathy and altruism than routine clinical contact with patients. This occurs because in real clinical situations the students feel overloaded by the pressure to avoid technical errors in their patient management and try not to get emotionally involved with them, for fear of that diverting them from the result that they deem essential in medical practice: to cure the disease. When watching a film, students are free from the imminent responsibility imposed on them in medical practice and can be more susceptible to emotional catharsis upon witnessing the patient's suffering when dealing with the disease, even if the situation and the characters depicted are fictional ${ }^{12}$.

The movies used in the intervention of this study have been used in several medical courses in numerous countries. The film The Doctor has been widely used as a pedagogical tool in the teaching of standards of behaviour to Medicine students, highlighting the inherent aspects of the patient-doctor relationship ${ }^{13}$, communication skills ${ }^{14}$, death and bereave- ment ${ }^{15}$. When watching the film, the students can be moved toward showing altruistic attitudes due to having gone through a psychological phenomenon called "elevation", described by Haidt $^{16}$ to designate the positive emotional experience gained by someone when witnessing another individual performing a virtuous act. Schnall et al. ${ }^{17}$ report that exposure, even if brief, to pro-social behaviour toward other individuals stimulates elevation, which, in turn motivates altruism. During the film, the main character demonstrates solidarity with a friend who is also undergoing treatment of advanced stage cancer, displaying benevolence toward her emotional suffering. The psychological phenomenon of elevation might have been responsible for the result found in this study. The students in general and, in particular, from the pre-clinical phase of the course displayed a significant change in humanistic attitudes in all the factors assessed on the IAA scale after watching the film, having internalized the virtuous act of the doctor represented in the film.

The other film used in the intervention, Still Alice, has been used as an instrument for reflection on perceptions held of Alzheimer disease patients, of the loss of autonomy suffered by those patients and the effects caused on the family dynamic resulting from the required care for a patient with a progressively invalidating neurological pathology ${ }^{18,19}$. It is possible that the students from the pre-clinical years, who displayed significant shift in attitudes towards mental health after the intervention, despite not yet having had any contact with psychiatric patients, were able to feel empathy for the character's life story when she starts to lose her social status, her career and her role in the family as a consequence of her mental illness.

When analysing the intern students' attitudes toward factor 4 (aspects related to mental health) after the intervention (Graph 3), no significant different was found ( $p>0.05$ ) when compared to the initial values. The students' emotional involvement with the film, which portrays a patient afflicted by a mental illness, may have failed to make enough impact to affect their attitudes in relation to the stigma associated to such patients. The difference in the behaviour of the pre-clinical students (Graph 2), who responded positively to the film, and the intern students suggests that contact with the psychiatric ward of a hospital environment might help shape student attitudes.

It should be highlighted that, at the time of the intervention, the fifth- and sixth-year students were doing rotation precisely on the Psychiatry module. Studies have demonstrated a the culture of stigmatization of psychiatric patients among health professionals in the hospital environment and that such a stigma is a factor that negatively influences students' atti- 
GRAPH 2

Graphic representation of the frequency of positive and negative attitudes of the group of students from the first, third and fourth years of the undergraduate medicine course at UNIFAP in a study conducted in Macapá in 2016.

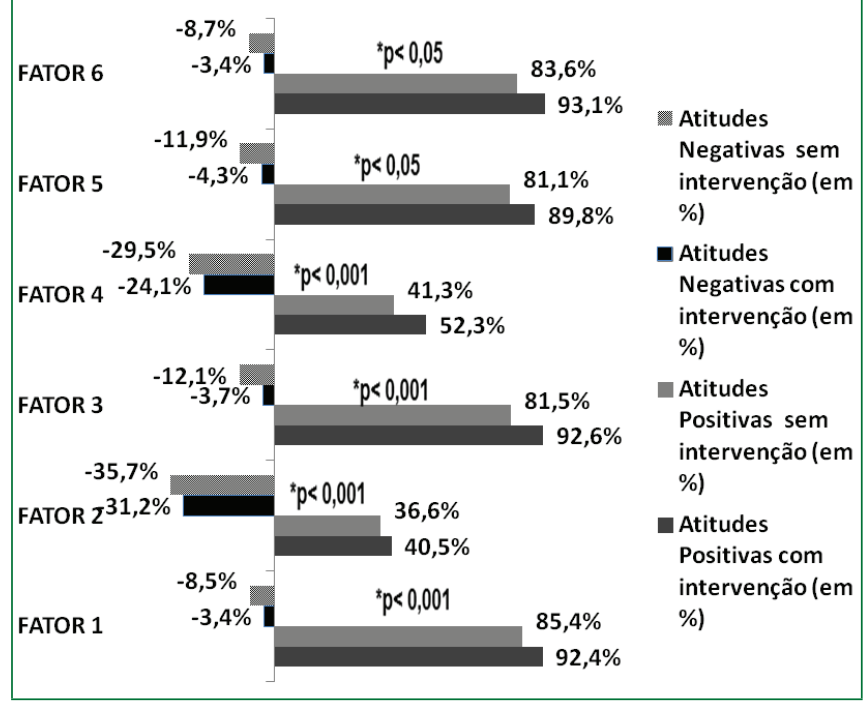

Source: Research record sheets.

Notes: Factor 1: psychological and emotional aspects in organic and mental diseases; Factor 2: aspects related to death; Factor 3: primary health care; Factor 4: aspects related to mental health; Factor 5: contribution with the scientific advance of medicine; Factor 6: other aspects of the physician's role.

tudes towards Psychiatry ${ }^{20,21}$. Totic et al. ${ }^{22}$, evaluating the attitudes and behaviours of medical students before and after the rotation in the psychiatric ward, observed that the sixth-year students, who had already completed their internship in that area, showed a greater tendency to stigmatize patients with mental illness. Kerby et al. ${ }^{23}$ found comparable results to those found in this study when investigating fourth-year medical students' attitudes toward mental health and psychiatry after a cinema session screening films with anti-stigma content. The authors demonstrated a significant increase in empathetic attitudes toward mental health following the intervention with films, however this effect petered out after completing internship in the Psychiatric area. The same phenomenon observed in this study could possibly be attributed to the fact that the students in the pre-clinical years, without the influence of having contact with psychopathological patients in the hospital environment, experienced the expected effect of the film: increased empathy in relation to those patients. However, the students who were already working as interns in the hospital's psychiatry ward were unable to change their stigmatizing view that they had witnessed in the company of health professionals in this area, even after intervention with the films.
The intern students also showed no significant change in attitudes after the intervention in relation to factor 2 , which corresponds to questions related to death (Graph 3). This factor was related to a high percentage of positive attitudes among these students before the cinema sessions (60.9\%). The percentage of positive responses to this factor was higher than the results found in other studies. Alves et al. ${ }^{24}$ applied the IAA scale to medical student interns and found a higher percentage of negative attitudes in the questions related to death (49.3\%). Mascia et al. ${ }^{25}$ found a higher percentage of conflicting attitudes (55\%) related to this same factor when assessing sixth-year medical students. These results demonstrate that, in this aspect, the UNIFAP intern students reported superior performance to students from the institutions where the other surveys were conducted. It is possible that the films exerted little impact on changing attitudes because the students already presented a high tendency to act positively in situations that involve death, leaving a small margin for increasing that tendency through the intervention executed. The positive attitudes of the final year students in relation to factor 2 were superior than those presented among students in the initial years of the course (Graph 2). One possible explanation for this finding would be the closer contact enjoyed by interns with patients during their hospital internships, as the literature has already demonstrated that students who had the opportunity to witness the death of patients were more susceptible to presenting positive attitudes toward the physician's responsibility for caring for end-of-life patients and offering support in the family's bereavement ${ }^{26}$.

Factor 5, corresponding to the contribution with the scientific advance of medicine, also demonstrated no significant change in the percentage of positive attitudes following the intervention among the student interns (Graph 3). The could be due to the group of students already presenting a high percentage of positive attitudes in this factor even before the intervention, as throughout the course they were encouraged to frequently read scientific texts and prepare for discussing topics in tutorials and in the other practical activities carried out in the first four years of the course, as well as in the discussions about clinical cases and articles that are used in the interns' theoretical studies. This fact would justify the difference in the behaviour of this group of students in relation to the pre-clinical students, who displayed increased positive attitudes after the intervention.

One surprising finding in the analysis of the general group of all the students from first to sixth year (Graph 1) is that they displayed changes in attitude toward factor 3 (primary health care) and factor 6 (other aspects of the physician's role) after the intervention, added to the fact that the first- to fourth-year 
GRAPH 3

Graphic representation of the frequency of positive and negative attitudes of the group of students from the fifth and sixth years of the undergraduate medicine course at UNIFAP in a study conducted in Macapá in 2016.

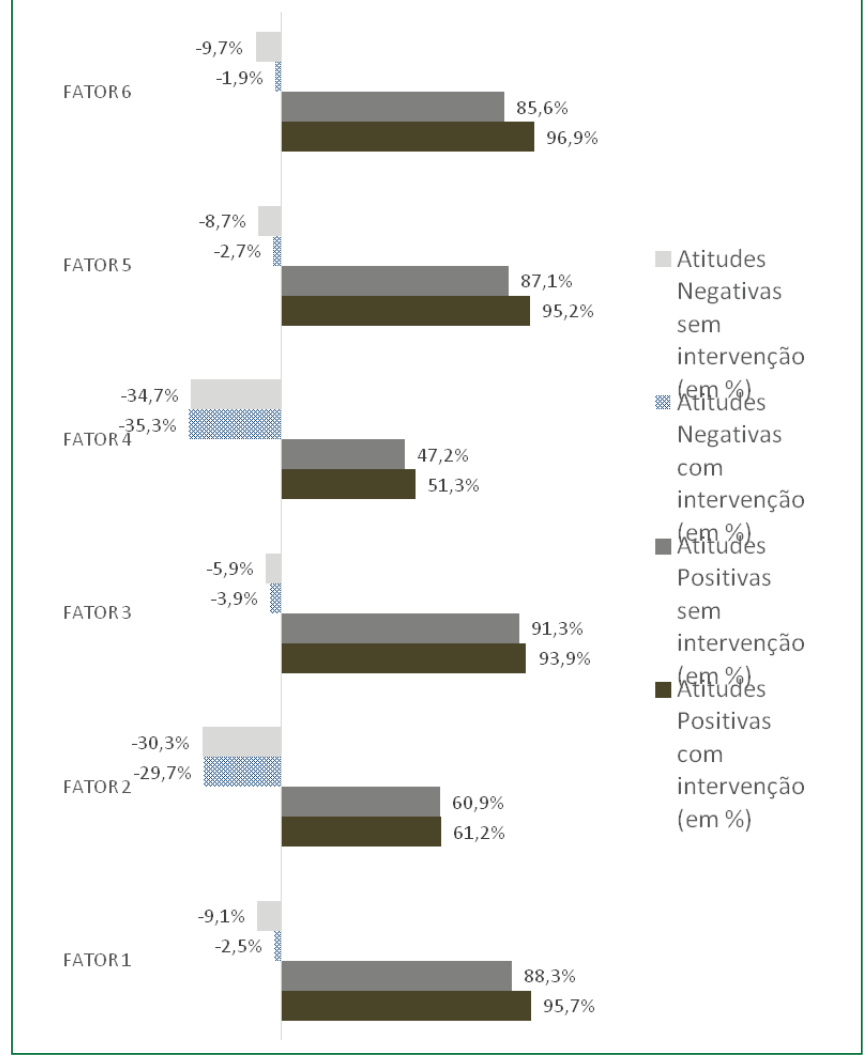

Source: Research record sheets.

Notes: Factor 1: psychological and emotional aspects in organic and mental diseases; Factor 2: aspects related to death; Factor 3: primary health care; Factor 4: aspects related to mental health; Factor 5: contribution with the scientific advance of medicine; Factor

6: other aspects of the physician's role.

students (Graph 2) also showed a significant increase in positive attitudes toward factor 5 (contribution with the scientific advance of medicine). This occurred despite these issues not being directly addressed in the films.

One explanation for this result might be that the intervention exerted a psychological effect on those students that was not restricted to the themes addressed in the films and discussions. It could be inferred from this that the formation of positive attitudes towards factors addressed in the films may have been generalised to encompass other stimuli that are not within one restricted area of comparison, as Doob asserts ${ }^{27}$.

In view of the findings of this research, we can infer that cinema is an effective pedagogical methodology in the teaching medical students affective skills, however it cannot be affirmed that the effect provoked in the students perpetuates throughout undergraduate training or even during future professional practice. From this perspective, Coulehan ${ }^{28}$ claims that repeated doses of the Dom Quixote effect can contribute to character development and suggests that, to maintain the temporary upsurge in altruistic feeling triggered by the cinema sessions, the students need to identify other routine practical situations in medicine that simulate that effect, attributing the teachers and preceptors with the responsibility of representing a professional model to be followed by their apprentices. However, what frequently happens during undergraduate medical training is that the students undergo a conflict of values, as the explicit medical curriculum in effect includes the teaching of empathy, professionalism and moral development as an objective, however those same students are exposed, especially during their medical intern years, to the hidden curriculum. And that has a greater impact on determining inadequate stances, such as disrespect in the relationship with the patient, abuse of power in the hierarchy established between teacher and student, as well as misalignment between the idealization medical practice, generally conveyed as a model of professionalism by the formal curriculum, and the actual clinical experiences of the students in the hospitals ${ }^{29,30}$.

Therefore, cinema should be used in medical education as a tool for teaching humanistic attitudes. However, to optimize its effect during internship and prolong it in the initial years of the course, the teachers need to appreciate the importance of ensuring a uniform standard behaviour that demonstrates competence and virtue, in keeping with the moral values that medical training aims to instil in future physicians.

\section{STUDY LIMITATIONS}

Despite the satisfactory results obtained, one can identify as a limitation of this study the failure to perform a sequential attitude assessment of these students throughout the entire undergraduate course in order to evaluate their commitment to maintaining a humanized posture in relation to patients, including after concluding the course and during their professional practice. Therefore, it cannot be inferred that this pedagogical strategy really has a significant impact on changing the profile of medics who undergo this experience in their training, bearing in mind the cross-sectional design of the study.

\section{CONCLUSION}

Cinema is an effective pedagogical tool in the teaching of humanistic attitudes during undergraduate medical training and should be systematically inserted into the pre-clinical years of Medicine courses as a complementary educational resource to 
teach students affective skills. During internship this educational resource could be used, but it is necessary to associate the method to a change in behaviour among health professionals in the hospital environment, for working alongside those with standards of behaviour that demonstrate stigma and lack of empathy toward patients overwhelms the beneficial psychological effects triggered by the films in medical students.

\section{ACKNOWLEDGMENTS}

We would like to express our sincere thanks to the author Maria de Fátima Avieiro Colares, for kindly making the instrument used in this research available.

\section{REFERÊNCIAS}

1. Colares MF, Troncon LE, Figueiredo JF, Cianflone AR, Rodrigues ML, Piccinato CE, et al. Construção de um instrumento para avaliação das atitudes de estudantes de medicina frente a aspectos relevantes da prática médica. Rev Bras Educ Med. 2002; 26 (3): 194-203.

2. Rennie SC, Rudland JR. Differences in medical students'attitudes to academic misconduct and reported behavior across the years- a questionnaire study. J Med Ethics. 2003 Apr; 29 (2): 97-102.

3. Woloschuk W, Harasym PH, Remple W. Attitude change during medical school: a cohort study. Med Educ. 2004; 38:522-34

4. Smith RC, Dorsey AM, Lyles JS, Frankel RM. Teaching self-awareness enhances learning about patiente-centered interviewing. Acad Med. 1999; 74(11): 1242-8.

5. Cohen LG, Sherif YA. Twelve tips on teaching and learning humanism in medical education. Med Teach. 2014; 36: 680-4.

6. Liao L. Opening our eyes to a critical approach to medicine: the humanities in medical education. Med Teach. 2017;39 (2): 220-1.

7. Schwartzstein RM. Getting the right medical students - nature versus nurture. NEJM. 2015; 372 (17): 1586-7.

8. Alexander M, Hall M, Pettice Y. Cinemeducation: a comprehensive guide to using film in medical education. Fam Med. 1994; 26:430-3.

9. Blasco PG, Gallian DM, Roncoletta AF, Moreto G. Cinema para o estudante de medicina: um recurso afetivo/efetivo na educação humanística. Rev Bras Edu Med. 2005; 29 (2): 119-28.

10. Kübler-Ross E. Sobre a morte e o morrer. 9th ed. São Paulo: WMF Martins Fontes; 2008.

11. McNeilly DP, Wengel SP. Teaching psychotherapeutic techniques to medical students. Acad Psychiatr. 2001; 25(4):193-200.
12. Shapiro J, Rucker L. The Don Quixote effect: why going to the movies can help develop empathy and altruism in medical students and residents. Families, System \& Health. 2004; 22(4):445-52.

13. Baños J. How literature and popular movies can help in medical education: applications for teaching the doctor-patient relationship. 2007. Med Educ;41: 915-20.

14. Alexander M. The doctor: a seminal video for cinemeducation. Fam Med. 2002; 34(2):92-4.

15. Byrne P. Why psychiatrists should watch films (or what has cinema ever done for psychiatry?). Advances in Psychiatric Treatment. 2009; 15:286-96.

16. Keyes CL, Haidt J. Flourishing: positive psychology and the life well-lived. Haidt J. Washington DC: American Psychology Association; 2003. Elevation and the positive psychology of morality; p. 275-289.

17. Schnall S, Roper J, Fessler DM. Elevation leads to altruistic behavior. Psychological Science. 2010; 21(3): 315-20.

18. Güércio NH. A arte de perder: os silenciamentos do mal de Alzheimer na maturidade feminina protagonista em para sempre alice. Revista de Comunicação da Universidade Católica de Brasília. 2016; 9(2):221-35.

19. Mullard A. The art of losing. The Lancet. 2015; 385 (9970):764.

20. Aydin N, Yigit A, Inandi T, Kirpinar I. Attitudes of hospital staff toward mentally ill patients in a teaching hospital. International Journal of Social Psychiatry. 2003; 49:17-26.

21. Dixon RP, Roberts LM, Lawrie S, Jones LA, Humphreys MS. Medical students' atitudes to psychiatric illness in primary care. Med Educ. 2008; 42(11): 1080-7.

22. Totic S, Stojiljkovic D, Pavlovic Z, Zaric N, Zarcovic B, Malic L, et al. Stigmatization of 'psychiatric label' by medical and non-medical students. International Journal of Social Psychiatry. 2011; 58 (5): 455-62.

23. Kerby J, Calton T, Dimambro B, Flood C, Glazebrook C. Anti-stigma films and medical students' attitudes towards mental illness and psychiatry: randomized controlled trial. Psychiatric Bulletin. 2008; 32:345-9.

24. Alves TL, Alves FV, Melo EV, Oliva-Costa EF. Evaluation of medical interns' attitudes towards relevant aspects of medical practice. Rev Assoc Med Bras. 2017; 63(6):492-9.

25. Mascia AR, Silva FB, Lucchese AC, De Marco MA, Martins MC, Martins LA. Atitudes frente a aspectos relevantes da prática médica: estudo transversal randomizado com alunos de segundo e sexto anos. Rev Bras Edu Med. 2009; 33(1): 40-8.

26. Wendy GA, Williams BS, Bost JE, Bernard D. Exposure to death is associated with positive attitudes and higher kno- 
wledge about end-of-life care in graduating medical students. J Palliat Med. 2008; 11(9):1227-33.

27. Doob LW. The behaviour of attitudes. Psychological Review. 1947; 54:135-156 apud Torres C., Neiva ER. Psicologia social: principais temas e vertentes. Porto Alegre: Artmed, 2011.

28. Coulehan J. The possible dream: a commentary on the Don Quixote effect. Families, System \& Health. 2004; 22(4): 453-6.

29. Coulehan J, Williams PC, Van McCrary S, Belling C. The best lack all conviction: biomedical ethics, professionalism, and social responsibility. Cambridge Quarterly of Healthcare Ethics. 2003; 12: 21-38.

30. Gaufberg EH, Batalden M, Sands R, Bell SK. The hidden curriculum: what can we learn from third-year medical student narrative reflection? Acad Med. 2010; 85 (11):1709-16.

\section{CONTRIBUTION OF THE AUTHORS}

1. Msc. Thaíla Soares da Costa Picanço:

- Autora principal, responsável pela idealização do projeto, revisão da literatura, aquisição dos dados e redação do manuscrito.

- Médica geriatra, preceptora do internato de Clínica Médica do curso de Medicina da Universidade Federal do Amapá (UNIFAP).

- Mestre em Ciências da Saúde pela Universidade Federal do Amapá.

- Local de trabalho: Hospital de Clínicas Alberto Lima (Macapá/AP).

- Email: thailapicanco@bol.com.br

2. Dra. Maira Tiyomi Sacata Tongu Nazima

- Orientadora do projeto de pesquisa, responsável pela revisão crítica do conteúdo intelectual.

- Doutorado em Medicina pela Universidade Federal de São Paulo.

- Médica oftalmologista, docente do curso de Medicina da Universidade Federal do Amapá (UNIFAP).

- Docente/orientadora do Programa de Mestrado em Ciências da Saúde da UNIFAP.

3. Msc. Bráulio Érison França dos Santos

- Responsável pela aquisição dos dados do projeto.

- Mestre em Ciências da Saúde pela Universidade Federal do Amapá.

- Médico perito, docente do curso de Medicina da Universidade Federal do Amapá (UNIFAP).
4. Msc. Olavo Magalhães Picanço Júnior

- Responsável pela aquisição dos dados do projeto.

- Mestre em Ciências pela Universidade Federal de São Paulo.

- Médico Oncologista, preceptor do internato de Clínica Cirúrgica do curso de Medicina da Universidade Federal do Amapá.

5. Msc. Leila do Socorro da Silva Morais

- Responsável pela aquisição dos dados do projeto.

- Médica Pneumologista, docente do curso de Medicina da Universidade Federal do Amapá.

- Mestre em Ciências da Saúde pela Universidade Federal do Amapá.

6. Msc. Maria Izabel de Albuquerque Cambraia

- Responsável pelo auxílio na interpretação dos dados do projeto em relação aos aspectos que envolvem a área da Psicologia.

- Psicóloga do Centro de Atenção Psicossocial Álcool e outras Drogas (CAPS-AD).

- Mestre em Ciências da Saúde pela Universidade Federal do Amapá.

7. Karina Suzany Nery Costa

- Responsável pelo auxílio na organização e tabulação dos dados do projeto.

- Médica graduada pela Universidade Federal do Amapá.

8. Luis Felipe da Silva Pena

- Responsável pelo auxílio na organização e tabulação dos dados do projeto.

- Médico graduado pela Universidade Federal do Amapá.

\section{CONFLICT OF INTEREST}

Declaro não haver conflito de interesse dos autores.

\section{CORRESPONDENCE ADDRESS}

thailapicanco@bol.com.br

Rodovia Juscelino Kubitscheck, $\mathrm{n}^{\text {o. }} 4.440$.

CEP: 68903-419

Macapá- AP 